\title{
A Study on the Operating Conditions to Eliminate Feedpipe Backmixing for Fast Competitive Reactions
}

\author{
Jeong-Gook Jang, Myung-Chan Jo ${ }^{1)^{*}}$ \\ Department of Energy Environmental Engineering, Dongseo University, Busan 617-718, Korea \\ ${ }^{1)}$ Department of Advanced Materials Engineering, Dongseo University, Busan 617-718, Korea \\ (Manuscript received 9 February, 2011; revised 18 June, 2011; accepted 21 July, 2011)
}

\begin{abstract}
A novel conductivity technique was developed to detect penetration depth of the vessel fluid into the feedpipe. For a given reactor geometry, critical agitator speeds were experimentally determined at the onset of feedpipe backmixing using Rushton 6 bladed disk turbine (6BD) and high efficiency axial flow type 3 bladed (HE-3) impellers. The ratio of the feedpipe velocity to the critical agitator speed $\left(\mathrm{v}_{\mathrm{f}} / \mathrm{v}_{\mathrm{t}}\right)$ was constant for either laminar or turbulent feedpipe flow regimes. Compared to the results of fast competitive reaction, feedpipe backmixing had to penetrate at least one feedpipe diameter into the feedpipe to significantly influence the yield of the side product. However, higher $\mathrm{v}_{\mathrm{f}} / \mathrm{v}_{\mathrm{t}}$ than that for $\mathrm{L} / \mathrm{d}=0$ (position at the feedpipe end) of the conductivity technique is recommended to completely eliminate feedpipe backmixing in conservative design criteria. The conductivity technique was successful in all feedpipe flow conditions of laminar, transitional and turbulent flow regimes.
\end{abstract}

Key Words : Conductivity technique, Feedpipe, Backmixing, Fast competitive reaction

\section{Introduction}

Mixing at the molecular scale, which is called micromixing, is important for fast, single-phase, competitive-consecutive reactions in a stirred tank reactor. Failure to properly mix the feed with the reactor contents often causes segregation and resultant inhomogeneity at the molecular scale. Segregation provides unfavorable conditions for competing side reactions and thus, can be a cause of a decrease in the yield of desired products (Taylor et al., 2005; Vicum et al., 2004). The undesirable products can results in contamination of the desirable products with potentially unusable products and increased separation costs.

${ }^{*}$ Corresponding author : Myung-Chan Jo, Department of Advanced Materials Engineering, Dongseo University, Busan 617-716, Korea

Phone: +82-51-320-1785

E-mail: mccho@dongseo.ac.kr
When the rate of chemical reaction is slow relative to mixing, there is no significant effect of mixing on the reaction rate or product distribution. For slow reactions, their rates are determined only by chemical kinetics, and there are no mixing effects. However, some chemical reactions are quite fast, e.g., neutralization, precipitation and combustion, so that adequate mixing on the molecular scale cannot be obtained (Bourne, 1982). The fastest reaction can go essentially to completion in the range of $10^{-3}$ to $10^{-6}$ second. Thus, for fast reactions a major portion of the reaction will occur immediately after the feed enters the reactor. So the conditions around the feedpipe are important.

Many experimental results have shown that the yield of desired products can be increased when the feed is introduced into the most turbulent region of the vessel which is near the impeller discharge zone 
(Belevi et al., 1981; Bourne et al., 1981a; Bourne et al., 1981b; Bourne and Rohani, 1983; Rice and Baud, 1990). However, high fluid velocity and intense turbulence can also cause feedpipe backmixing. Feedpipe backmixing is the phenomenon of reactor contents migrating back into the feedpipe caused by high agitation intensity in the vessel. The relatively mild turbulence condition within the feedpipe can promote side reactions.

A typical form of the fast competitive-consecutive reaction is as follows:

$$
\begin{aligned}
& \mathrm{A}+\mathrm{B} \rightarrow \mathrm{R} \\
& \mathrm{R}+\mathrm{B} \rightarrow \mathrm{S}
\end{aligned}
$$

Typical examples of the above type reactions are coupling of 1-naphthol with diazotized sulphanilic acid and iodination of L-tyrosine. In a fedbatch reactor, A is initially charged to the reactor, and B is added at a set feed rate and is the limiting agent. At the start of the reactions, $B$ will react with $A$ and $R$ will be formed. If reaction zones are completely mixed down to the molecular scale, B will be totally consumed to form $\mathrm{R}$ and only $\mathrm{A}$ and $\mathrm{R}$ will exist after the reactions are completed. When, however, mixing at the molecular scale is poor, there will be unreacted $\mathrm{B}$ remaining even after $\mathrm{R}$ has been formed. This unreacted $B$ will react with $\mathrm{R}$ to form $\mathrm{S}$ which is an unwanted product, and thus, the overall yield will be lowered.

Selectivity for an undesirable product $\mathrm{S}$ is defined as follows:

$$
\mathrm{X}_{\mathrm{S}}=\frac{2 \mathrm{C}_{\mathrm{Sf}}}{\left(2 \mathrm{C}_{\mathrm{Sf}}+\mathrm{C}_{\mathrm{Rf}}\right)}=\frac{2 \mathrm{C}_{\mathrm{sf}}}{\mathrm{C}_{\mathrm{B} 0}}
$$

$\mathrm{X}_{\mathrm{S}}$ is the parameter for the degree of segregation for the fast competitive-consecutive reactions. $\mathrm{X}_{\mathrm{S}}$ decreases as mixing at the molecular scale increases. Many experimental results have demonstrated that $\mathrm{X}_{\mathrm{S}}$ can be lowered by introducing the feed near the impeller where the feed stream is mixed most rapidly with the bulk fluid. The intensity of mixing can be increased and subsequently, $X_{S}$ can be decreased by increasing the agitator speed for a given feedpipe location.

Another form of fast parallel reaction is acid-base neutralization and alkaline hydrolysis of ethyl chloroacetate and is as follows:

$$
\begin{aligned}
& \mathrm{NaOH}(\mathrm{A})+\mathrm{HCl}(\mathrm{B}) \rightarrow \mathrm{NaCl}(\mathrm{P})+\mathrm{H}_{2} \mathrm{O} \\
& \mathrm{NaOH}(\mathrm{A})+\mathrm{CH}_{2} \mathrm{ClCOOC}_{2} \mathrm{H}_{5}(\mathrm{C}) \\
\rightarrow & \mathrm{CH}_{2} \mathrm{ClCOONa}(\mathrm{Q})+\mathrm{C}_{2} \mathrm{H}_{5} \mathrm{OH}
\end{aligned}
$$

In a fedbatch reactor, $\mathrm{B}$ and $\mathrm{C}$ are premixed in the reactor and $\mathrm{A}$ is added at a feed rate and is the limiting agent. When mixing is perfect, there is no mixing effect on the product distribution and $\mathrm{Q} / \mathrm{P}$. However, when segregation is intense, the product distribution becomes independent of chemical kinetics and only depends upon the ratio of the concentrations of reagents $\mathrm{B}$ and $\mathrm{C}$.

The yield of $\mathrm{Q}$ is defined as follows:

$$
\mathrm{X}_{\mathrm{Q}}=1-(\mathrm{a}+1) \frac{\mathrm{C}_{\mathrm{c}}}{\mathrm{C}_{\mathrm{A}_{0}}}=(\mathrm{a}+1) \frac{\mathrm{C}_{\mathrm{Et}}}{\mathrm{C}_{\mathrm{A}_{0}}}
$$

When the first reaction between $\mathrm{A}$ and $\mathrm{B}$ occurs instantaneously, $\mathrm{X}_{\mathrm{Q}}$ is 0 with perfect mixing and approaches $1 / 2$ (with $\mathrm{C}_{\mathrm{B}_{0}}=\mathrm{C}_{\mathrm{C}_{0}}$ ) in highly segregated conditions.

As discussed above, proper mixing at the molecular scale is essential to suppress the competing side reactions. Proper mixing can be achieved by locating the feedpipe in the impeller discharge stream which is the most turbulent region of the vessel. However, high fluid velocity and intense turbulence can cause feedpipe backmixing to lower the yield of desired product. 
The detrimental effect of feedpipe backmixing was first reported by Bourne et al. (1981b). They demonstrated that feedpipe backmixing could significantly lower the yield of the primary product for the fast competitive-consecutive reaction. For their lowest feedpipe velocity and highest impeller rotational speed, backmixing increased the yield of the side product 10 fold.

Several studies had been attempted to determine the conditions to eliminate feedpipe backmixing. Fasano and Penney (1991) have recommended that $\mathrm{V}_{\mathrm{f}} / \mathrm{v}_{\mathrm{t}}$ be greater than 0.5 to eliminate feedpipe backmixing with the feedpipe positioned in the impeller discharge stream. However, their recommendation was based not on experimental results, but on the knowledge of turbulent intensity in agitated vessel.

Fasano et al. (1992) used a visual dye technique and determined agitator speed needed to eliminate feedpipe backmixing for a given impeller type and for a given feedpipe velocity and location. A $0.95 \mathrm{~cm}$ diameter tube through which dye was injected was inserted through the feedpipe, and positioned at the centerline. They determined the agitator speed when a centerline injected dye migrated back into the feedpipe. However, the visual dye technique was not successful for turbulent conditions in the feedpipe, because the dye was dispersed very fast in highly turbulent fluid, and the naked eye could not follow the movement of the dye. Therefore, operating conditions of their experiments were limited to laminar flow conditions with maximum feedpipe Reynolds number, $\mathrm{N}_{\text {Ret }}$, of 1,300 .

In industry, most fast reactions are conducted in turbulent flow conditions. Therefore, a novel conductivity technique was developed in this study to detect feedpipe backmixing in all laminar, transitional, and turbulent flow conditions. Critical agitator speeds to eliminate feedpipe backmixing were determined for a given feedpipe velocity, feedpipe location, and impeller type. In addition, fast competitive reaction was conducted and the results were analyzed with the $\mathrm{v}_{\mathrm{f}} / \mathrm{v}_{\mathrm{t}}$ values determined from the conductivity technique to eliminate feedpipe backmixing.

\section{Materials and Methods}

Fig. 1 shows the stirred tank reactor for feedpipe backmixing experiment. The inside diameter and height of the Plexiglass vessel were $24.27 \mathrm{~cm}$ and $24.13 \mathrm{~cm}$, respectively. Tap water was fed through the feedpipe and overflow was drained through a pipe at the top plate of the vessel. A Graham Model E29VF variable speed drive was used to vary the impeller rotational speed which was measured by an Airpax (Model 77220-1-201) digital tachometer. A Schutte-Koering Rotameter (Model 20-7050) was used to measure the feedpipe flowrate. The glass feedpipe was positioned either at the radial direction towards the centerline or above the impeller at a radial location of $3.8 \mathrm{~cm}$ from the vertical centerline of the vessel.

The conductivity electrode was installed in a glass feedpipe and connected to a Pen-Chart Recorder (Linear Model 585). The feedpipe was $1.27 \mathrm{~cm}$ outside and $0.95 \mathrm{~cm}$ inside diameter glass tubing. An insulated $0.05 \mathrm{~cm}$ diameter platinum wire was inserted through a $0.3 \mathrm{~cm}$ diameter stainless steel tube and the tube was installed along the center of the feedpipe through a Swagelok fitting. The gap between the stainless steel tube and the platinum wire was filled by epoxy in order to fix the wire and electrically isolate between them. The stainless steel tube was used to hold the wire and used as the counter electrode. The other ends of the platinum wire and stainless steel tube were connected to the Pen-Chart Recorder through a designed external electric circuit.

In order to detect the signal from the conductivity electrodes, an electric circuit was designed and 


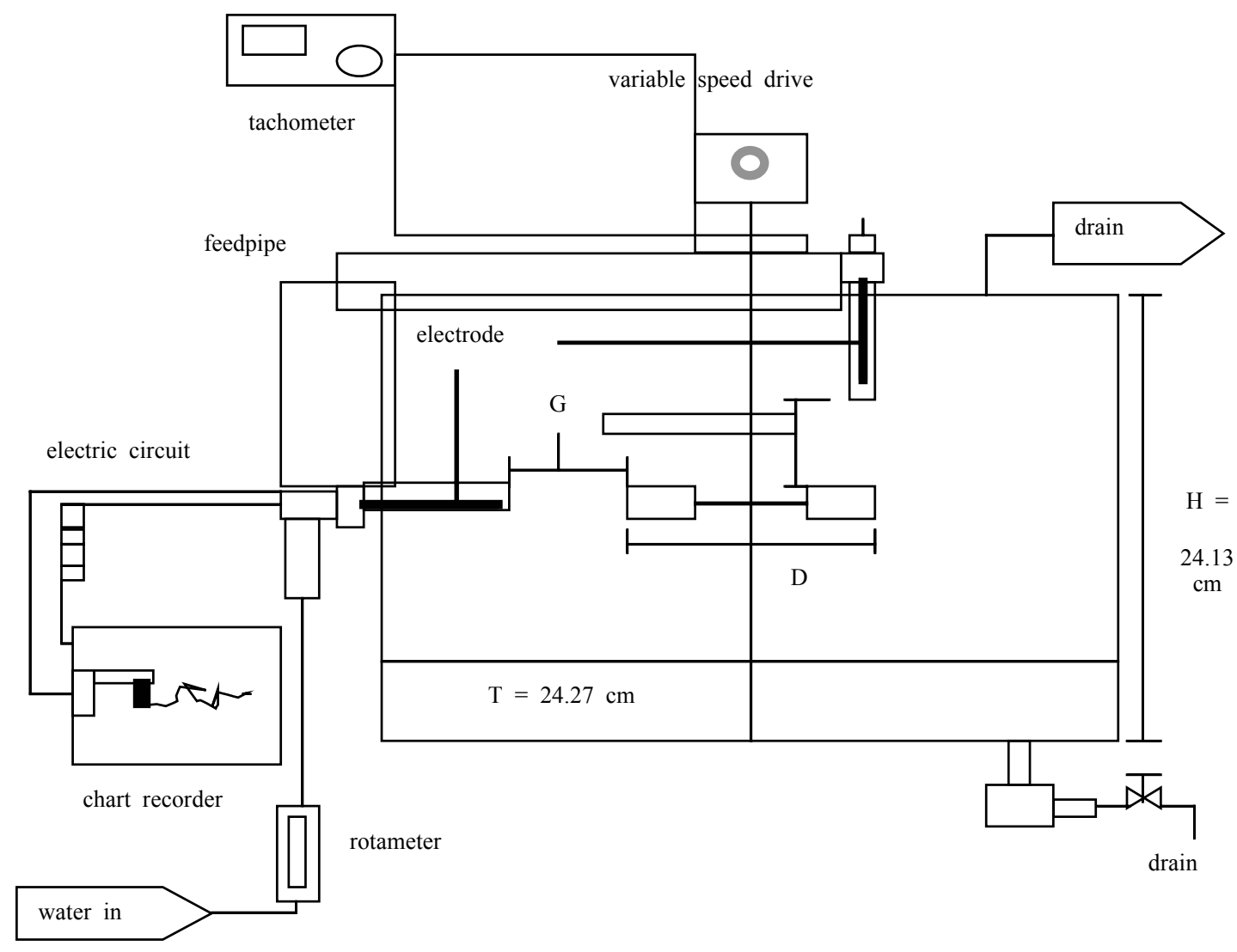

Fig. 1. Schematic diagram of feedpipe backmixing experiment.

connected to the Pen-Chart Recorder. It was composed of $6 \mathrm{~V}$ battery as E.M.F. and two resistances. One was the resistance of an external resistor, $\mathrm{R}_{\mathrm{e}}$, and another was the resistance of tap water between the conductivity electrodes, $\mathrm{R}_{\mathrm{P}}$. It was found that the sensitivity of the voltage change according to the change in $R_{P}$ was maximum when $R_{e}$ $=\mathrm{R}_{\mathrm{P}}$. The measured $\mathrm{R}_{\mathrm{P} \text { was } 16,000 \Omega \text { and thus, } 16,000 \Omega \text { of Re Was }}$ used in this experiment. The resistance of $R_{P}$ was hooked up across the Pen-Chart Recorder.

Initially, the vessel was charged with $\mathrm{NaCl}$ solution. Tap water was started to flow through the feedpipe in which the conductivity electrodes were installed. If an agitator speed is high enough to force the vessel fluid into the feedpipe for a given feedpipe velocity, the $\mathrm{NaCl}$ solution will penetrate into the feedpipe to reach the electrodes and thus, increase the conductivity around the electrodes. Therefore, there will be a resistance drop in the resistance, $R_{P}$, and subsequently, voltage drop across the $\mathrm{R}_{\mathrm{P}}$. This voltage drop will cause a change in the input signal to the Recorder to cause a peak.

The agitator speed was increased with $5 \%$ increments until detectable peaks were observed on the Recorder. Once feedpipe backmixing was detected by the peaks, the speed was determined as the critical agitator speed, $\mathrm{N}_{\mathrm{c}}$. While running the experiment, $25 \mathrm{wt} \% \mathrm{NaCl}$ solution was added to keep the bulk concentration at about $40 \mathrm{mmol} /$ liter in the vessel. The resolution of the conductivity technique 
was found to be on the order of $10^{-5} \mathrm{~mole} / \mathrm{liter}$. Compared to the bulk concentration of $40 \mathrm{mmol} / \mathrm{liter}$, the conductivity technique could detect 1,000 times diluted concentration of $\mathrm{NaCl}$ solution in the vessel when feedpipe backmixing occurred (Jo et al., 1997).

In this experiment, Rushton 6 bladed disk turbine (6BD) and high efficiency axial flow type 3 bladed (HE-3) impellers with 8.90 and $12.70 \mathrm{~cm}$ diameters were used. The dimensions of the impellers are given in Table 1.

Table 1. Dimensions of impellers used for feedpipe backmixing experiment

\begin{tabular}{cccccc}
\hline Type & $\begin{array}{c}\mathrm{D} \\
(\mathrm{cm})\end{array}$ & $\begin{array}{c}\mathrm{W}_{\mathrm{h}} \\
(\mathrm{cm})\end{array}$ & $\begin{array}{c}\mathrm{W} \\
(\mathrm{cm})\end{array}$ & $\begin{array}{c}\mathrm{D}_{\mathrm{d}} \\
(\mathrm{cm})\end{array}$ & $\begin{array}{c}\mathrm{d}_{\mathrm{s}} \\
(\mathrm{cm})\end{array}$ \\
\hline \hline 6BD & 8.90 & 1.78 & 2.23 & 5.89 & 1.27 \\
\hline 6BD & 12.70 & 2.54 & 3.18 & 5.89 & 1.27 \\
\hline HE-3 & 8.90 & N/A & N/A & N/A & 1.27 \\
\hline HE-3 & 12.70 & N/A & N/A & N/A & 1.27 \\
\hline
\end{tabular}

Typical fast competitive reaction experiment was conducted to investigate the effect of feedpipe backmixing on the product distribution. Acid-bas neutralization and alkaline hydrolysis of ethyl chloroacetate was selected as the test reaction. The yield $\mathrm{X}_{\mathrm{Q}}$ was determined using equation (2) from $\mathrm{C}_{\mathrm{Et}}$ in this experiment. Concentration of ethanol, $\mathrm{C}_{\mathrm{Et}}$, was analyzed using a HP 5859 Gas Chromatography. Experiments were conducted in 19.6 and 177.9 liter reactors with Rushton 6BD impellers. Dimensions of the reactors and impellers are given in Table 2.

Table 2. Dimensions of reactors and impellers for the reaction experiment

\begin{tabular}{cccccccc}
\hline $\begin{array}{c}\text { Reactor } \\
\text { volume } \\
(\text { liter })\end{array}$ & $\begin{array}{c}\mathrm{T} \\
(\mathrm{cm})\end{array}$ & $\begin{array}{c}\mathrm{H} \\
(\mathrm{cm})\end{array}$ & $\begin{array}{c}\mathrm{D} \\
(\mathrm{cm})\end{array}$ & $\begin{array}{c}\mathrm{G} \\
(\mathrm{cm})\end{array}$ & $\begin{array}{c}\mathrm{W}_{\mathrm{h}} \\
(\mathrm{cm})\end{array}$ & $\begin{array}{c}\mathrm{W} \\
(\mathrm{cm})\end{array}$ & $\begin{array}{c}\mathrm{D}_{\mathrm{d}} \\
(\mathrm{cm})\end{array}$ \\
\hline 19.6 & 29.21 & 29.21 & 9.74 & 2.51 & 1.91 & 2.38 & 6.51 \\
\hline 177.9 & 60.96 & 60.96 & 20.32 & 5.13 & 3.98 & 4.97 & 13.58 \\
\hline
\end{tabular}

Equal molar quantities of $\mathrm{A}, \mathrm{B}$, and $\mathrm{C}$ were used because the product distribution is sensitive to stoichiometry. The solutions of $\mathrm{B}$ and $\mathrm{C}$ were premixed and then, aqueous solution of $\mathrm{A}$ was added to the reactor through a feedpipe located above the impeller.

\section{Results and Discussion}

Feedpipe was located either radially in the midplane of the impeller or above the impeller. Two positions were tested for the radial orientation and one for the above impeller location. The penetration depth of the feedpipe backmixing was determined by varying the location of the electrode in the feedpipe. That is, distance of the platinum electrode tip from the end of the feedpipe, L, was varied from $0,0.32$, 0.64 and $1.0 \mathrm{~cm}$.

3.1. Variation of critical agitator speed, $\mathrm{N}_{\mathrm{C}}$, with feedpipe Reynolds number, $\mathrm{N}_{\text {Ret }}$

Figs. 2 and 3 present representative plots of $\mathrm{N}_{\mathrm{C}}$ vs $\mathrm{N}_{\text {Ret }}$ for the $12.70 \mathrm{~cm} \mathrm{6BD}$ and HE-3 impellers, respectively. As shown in the Figs. 2 and 3, $\mathrm{N}_{\mathrm{C}}$ always increased with $\mathrm{N}_{\text {Ret }}$ for $\mathrm{N}_{\text {Ret }}<800$ as $\mathrm{N}_{\text {Ret }}$ was increased for a given $\mathrm{L} / \mathrm{d}$. However, for $\mathrm{L} / \mathrm{d}=0.33$ and $0.67, \mathrm{~N}_{\mathrm{C}}$ decreased in the feedpipe transition flow regime for $800<\mathrm{N}_{\text {Ret }}<1,000$. These behaviors indicated that the feedpipe flow probably started becoming turbulent at $\mathrm{N}_{\text {Ret }}=800$. Actually, in this transition flow regime, there existed triple values of $\mathrm{N}_{\text {Ret }}$ for a given impeller rotational speed, $\mathrm{N}_{C}$. These results also indicated that feedpipe backmixing occurred more readily for turbulent feedpipe flow conditions than laminar feedpipe flow conditions.

For laminar flow in the feedpipe, the maximum velocity is twice the average velocity. For turbulent flow in the feedpipe, the maximum velocity is about 1.1 times the average velocity and thus, turbulent flow in the feedpipe is thought to be more easily 


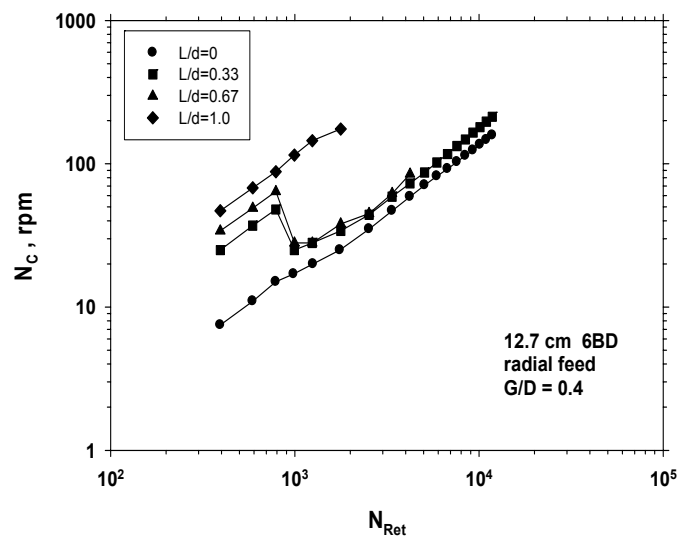

Fig. 2. Plot of $\mathrm{NC}$ vs $\mathrm{N}_{\mathrm{Ret}}$ for radial feed, for $12.7 \mathrm{~cm} 6 \mathrm{BD}$ and for $\mathrm{G}=5.08 \mathrm{~cm}$.

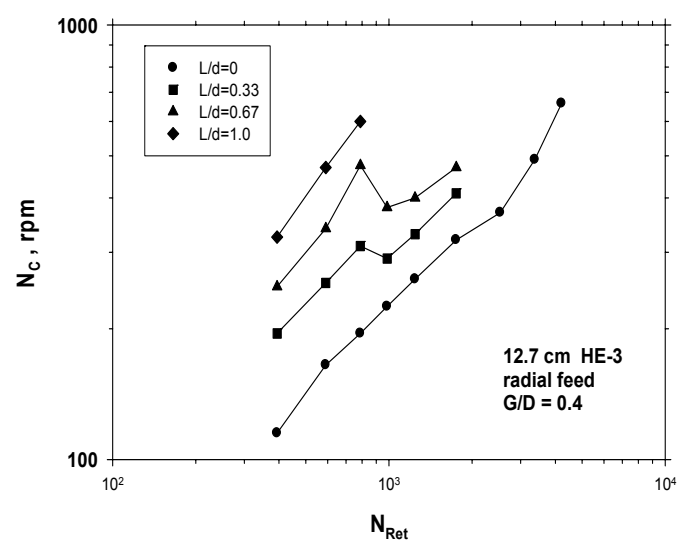

Fig. 3. Plot of $N_{C} v s N_{\text {Ret }}$ for radial feed, for $12.7 \mathrm{~cm} \mathrm{HE}-3$ and for $\mathrm{G}=5.08 \mathrm{~cm}$.

penetrated at the feedpipe centerline by the turbulent burst of the vessel fluid. Another possible explanation is that in the laminar feedpipe flow conditions, flow is streamlined and thus, all the flow will be counter to the penetrating burst of the vessel fluid. If turbulence develops in the feedpipe, some part of the flow will not be streamlined and may be rotational. Therefore, the change of the direction of the feedpipe flow may have helped the penetration of the burst of the vessel fluid into the feedpipe to cause the drop of $\mathrm{N}_{\mathrm{C}}$ at the start of the transition flow regime. As $\mathrm{N}_{\text {Ret }}$ was further increased, $\mathrm{N}_{\mathrm{C}}$ eventually increased as the flow became increasingly turbulent.

There were no drops of $\mathrm{N}_{\mathrm{C}}$ in the transition regime when the electrode was positioned either at the end of the feedpipe $(\mathrm{L} / \mathrm{d}=0)$ or one feedpipe diameter into the feedpipe $(\mathrm{L} / \mathrm{d}=1.0)$. For $\mathrm{L} / \mathrm{d}=1.0$, turbulence of the feedpipe flow was thought not to be high enough to cause feedpipe backmixing at a lower impeller rotational speed than that in the laminar regime because the electrode was positioned too far from the feedpipe end for the penetrating burst of the vessel fluid to reach the electrode. For $\mathrm{L} / \mathrm{d}=0$, the electrode is exposed directly to the vessel fluid flow and thus, the direct influence of the vessel fluid flow was thought to dominate over the influence of the turbulence of the feedpipe flow in the transition regime.

\subsection{Trend of $v_{f} / v_{t}$ vs $N_{\text {Ret }}$}

Plots of $\mathrm{v}_{\mathrm{f}} / \mathrm{v}_{\mathrm{t}}$ vs $\mathrm{N}_{\text {Ret }}$ for all feedpipe locations, for all type of impellers and electrode positions are presented in Figs. 4 to 15. As shown in the Figs., the values of $v_{f} / v_{t}$ were essentially constant for either laminar $\left(\mathrm{N}_{\text {Ret }}<800\right)$ or fully turbulent flow $\left(\mathrm{N}_{\text {Ret }}>\right.$ 3,000 for radial feed, $\mathrm{N}_{\mathrm{Ret}}>2,000$ for above feed) in the feedpipe. For $\mathrm{L} / \mathrm{d}=0.33$ and $0.67, \mathrm{v}_{\mathrm{f}} / \mathrm{v}_{\mathrm{t}}$ increased sharply in the transition regime. As discussed earlier, the increase of $\mathrm{v}_{\mathrm{f}} / \mathrm{v}_{\mathrm{t}}$ was due to the drop of $\mathrm{N}_{\mathrm{C}}$ in the transition regime as $\mathrm{v}_{\mathrm{f}}$ was increased. For $\mathrm{L} / \mathrm{d}=0$ and 1.0, there were slight increases of $\mathrm{v}_{\mathrm{f}} / \mathrm{v}_{\mathrm{t}}$ in the transition regime because there were no significant decreases of $\mathrm{N}_{\mathrm{C}}$.

The values of $\mathrm{v}_{\mathrm{f}} / \mathrm{v}_{\mathrm{t}}$ in the laminar flow regime were always lower than those in the turbulent flow regime. The results indicate that it is more difficult the vessel fluid penetrate into the feedpipe counter to laminar flow than turbulent flow in the feedpipe.

As shown in the Figs. 8 and 9, the values of $\mathrm{v}_{\mathrm{f}} / \mathrm{v}_{\mathrm{t}}$ for the above feedpipe location were significantly 


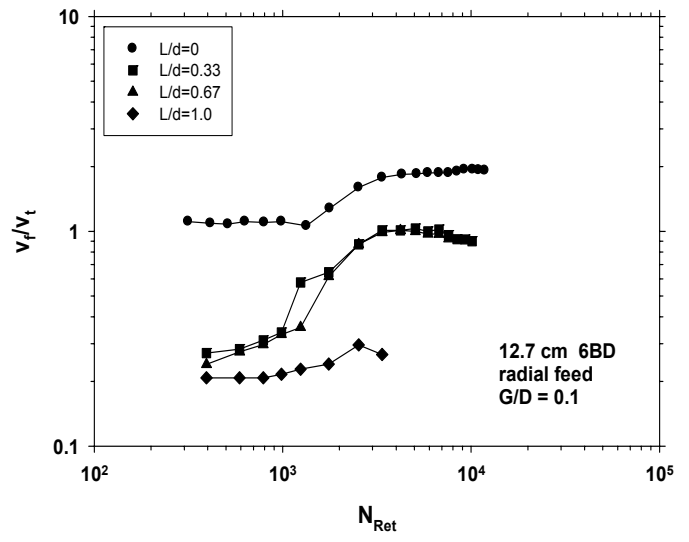

Fig. 4. Plot of $v_{f} / v_{t}$ vs $N_{\text {Ret }}$ for radial feed, for $12.7 \mathrm{~cm} 6 \mathrm{BD}$ and for $\mathrm{G}=1.27 \mathrm{~cm}$.

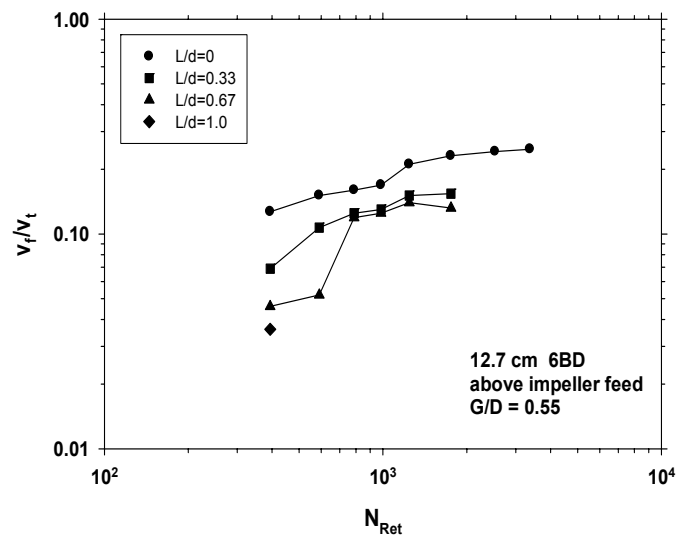

Fig. 6. Plot of $\mathrm{v}_{\mathrm{f}} / \mathrm{v}_{\mathrm{t}}$ vs $\mathrm{N}_{\text {Ret }}$ for above impeller feed, for 12.7 $\mathrm{cm} 6 \mathrm{BD}$ and for $\mathrm{G}=6.99 \mathrm{~cm}$.

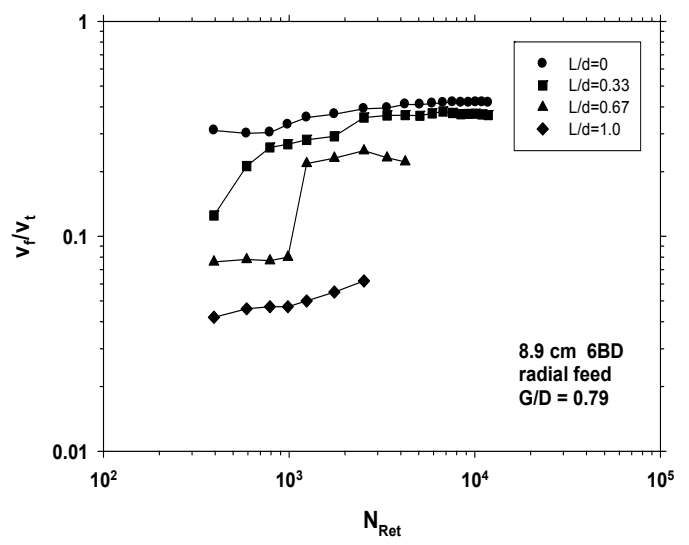

Fig. 8. Plot of $\mathrm{v}_{\mathrm{f}} / \mathrm{v}_{\mathrm{t}} \mathrm{vs} \mathrm{N}_{\text {Ret }}$ for radial feed, for $8.9 \mathrm{~cm} 6 \mathrm{BD}$ and for $\mathrm{G}=6.99 \mathrm{~cm}$.

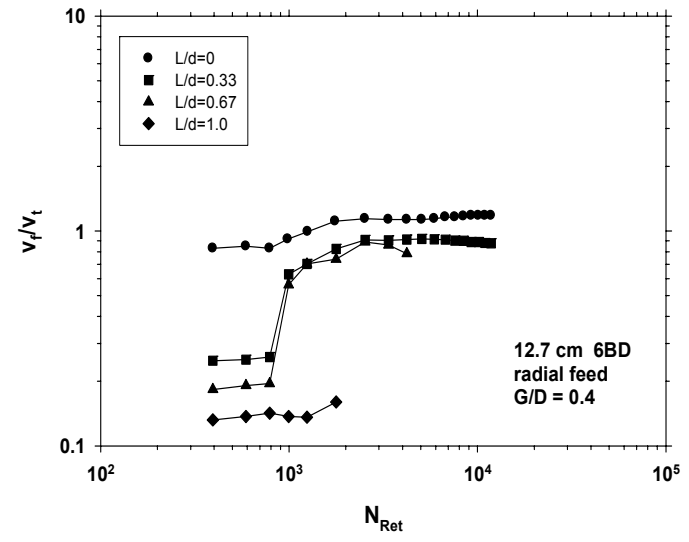

Fig. 5. Plot of $\mathrm{v}_{\mathrm{f}} / \mathrm{v}_{\mathrm{t}}$ vs $\mathrm{N}_{\text {Ret }}$ for radial feed, for $12.7 \mathrm{~cm} 6 \mathrm{BD}$ and for $\mathrm{G}=5.08 \mathrm{~cm}$.

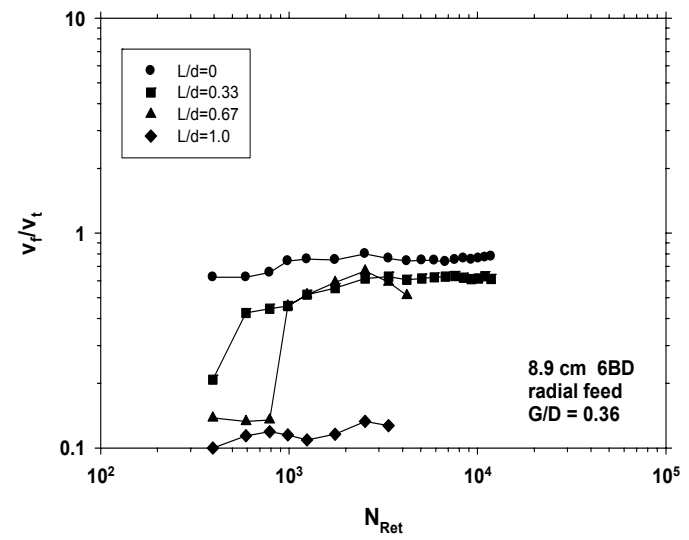

Fig. 7. Plot of $\mathrm{v}_{\mathrm{f}} / \mathrm{v}_{\mathrm{t}}$ vs $\mathrm{N}_{\text {Ret }}$ for radial feed, for $8.9 \mathrm{~cm} 6 \mathrm{BD}$ and for $\mathrm{G}=3.18 \mathrm{~cm}$.

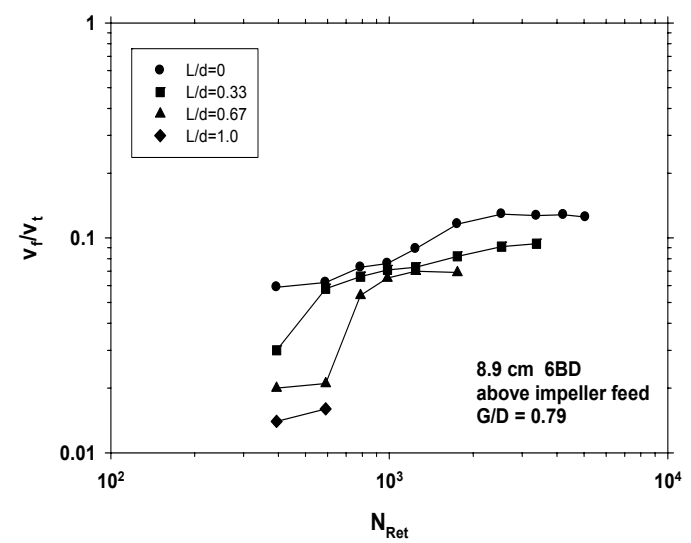

Fig. 9. Plot of $v_{f} / v_{t}$ vs $N_{\text {Ret }}$ for above impeller feed, for 8.9 $\mathrm{cm} 6 \mathrm{BD}$ and for $\mathrm{G}=6.99 \mathrm{~cm}$. 


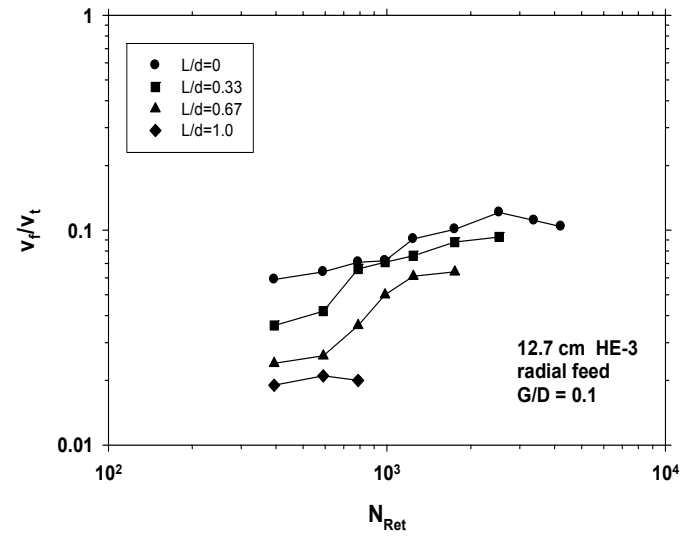

Fig. 10. Plot of $\mathrm{v}_{\mathrm{f}} / \mathrm{v}_{\mathrm{t}}$ vs $\mathrm{N}_{\text {Ret }}$ for radial feed, for $12.7 \mathrm{~cm} \mathrm{HE}$ -3 and for $\mathrm{G}=1.27 \mathrm{~cm}$.

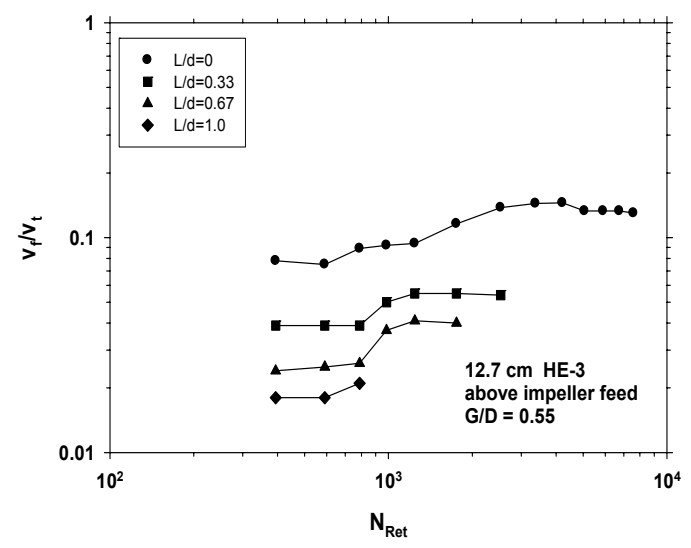

Fig. 12. Plot of $v_{f} / v_{t}$ vs $N_{\text {Ret }}$ for above impeller feed, for $12.7 \mathrm{~cm} \mathrm{HE}-3$ and for $\mathrm{G}=6.99 \mathrm{~cm}$.

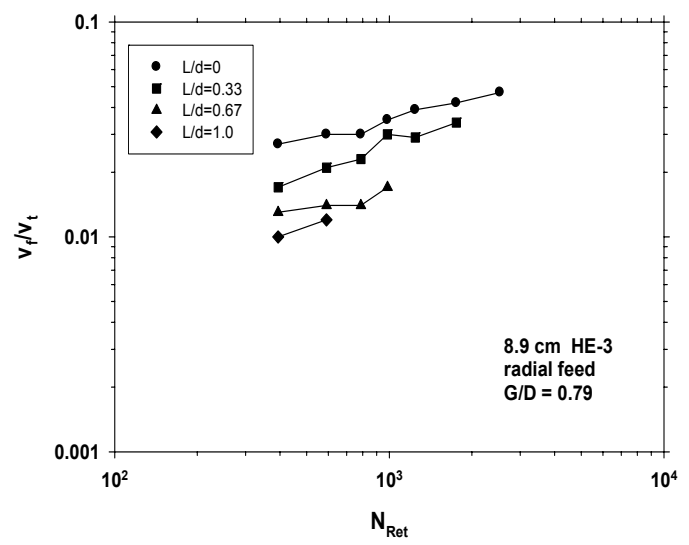

Fig. 14. Plot of $\mathrm{v}_{\mathrm{f}} / \mathrm{v}_{\mathrm{t}}$ vs $\mathrm{N}_{\text {Ret }}$ for radial feed, for $8.9 \mathrm{~cm} \mathrm{HE}^{-}$ 3 and for $\mathrm{G}=6.99 \mathrm{~cm}$.

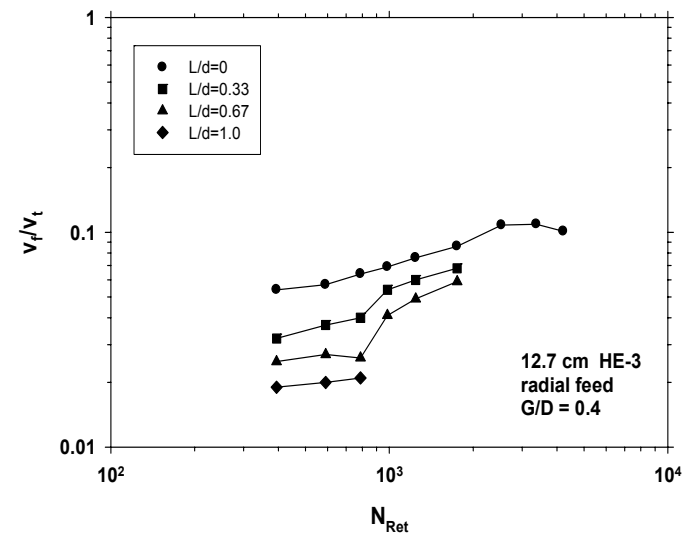

Fig. 11. Plot of $v_{f} / v_{t}$ vs $N_{\text {Ret }}$ for radial feed, for $12.7 \mathrm{~cm} \mathrm{HE}$ -3 and for $\mathrm{G}=5.08 \mathrm{~cm}$.

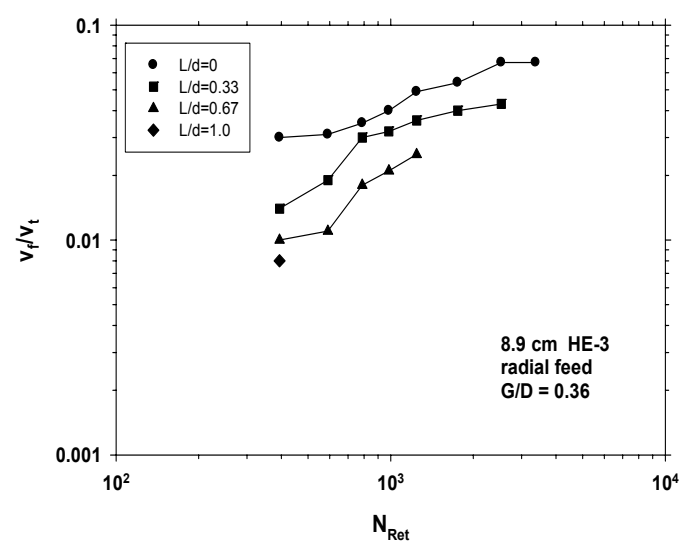

Fig. 13. Plot of $v_{f} / v_{t}$ vs $N_{\text {Ret }}$ for radial feed, for $8.9 \mathrm{~cm} \mathrm{HE}^{-}$ 3 and for $\mathrm{G}=3.18 \mathrm{~cm}$.

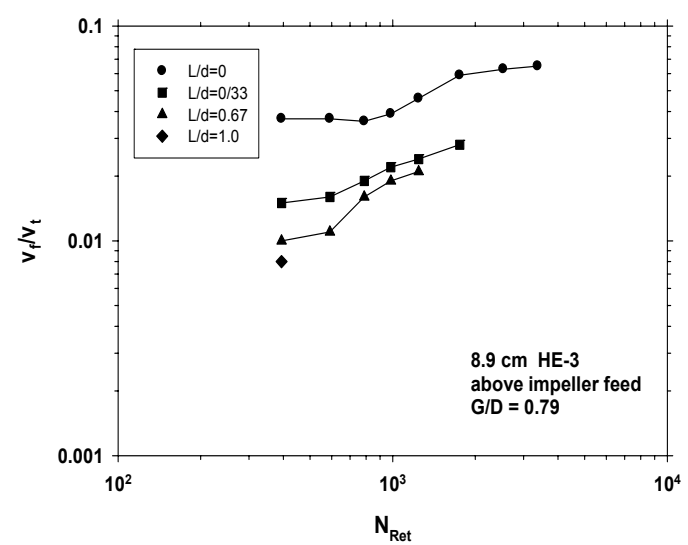

Fig. 15. Plot of $\mathrm{v}_{\mathrm{f}} / \mathrm{v}_{\mathrm{t}} \mathrm{Vs} \mathrm{N}_{\text {Ret }}$ for above impeller feed, for 8.9 $\mathrm{cm} \mathrm{HE}-3$ and for $\mathrm{G}=6.99 \mathrm{~cm}$. 
lower (about 4 time) than those for the radial feedpipe location for the same $\mathrm{G} / \mathrm{D}=0.79$. These results can be ascribed by the fact that the $6 \mathrm{BD}$ impeller is a radial flow impeller and has a principal direction of discharge normal to the axis of rotation. Therefore, the velocity from the disk impeller is much higher in the radial direction than in the vertical direction. The decreases of $\mathrm{v}_{\mathrm{f}} / \mathrm{v}_{\mathrm{t}}$ for the above feedpipe location could be explained by that sense. On the other hand, the values of $\mathrm{v}_{\mathrm{f}} / \mathrm{v}_{\mathrm{t}}$ for the above feedpipe location were higher than those for the radial feedpipe location for the HE-3 impeller with the same G/D = 0.79 as can be seen in the Figs. 14 and 15. The HE-3 impeller is an axial flow impeller and thus, has higher velocity in axial direction than that in the radial direction.

Especially for the radial direction, the values of $\mathrm{v}_{\mathrm{f}} / \mathrm{v}_{\mathrm{t}}$ for the 6BD impellers were almost 10 times higher than those for the HE-3 impellers as can be seen in the Figs. 4 to 8 and Figs. 10 to 14 . These results also indicated that much lower impeller rotational speeds were needed for the 6BD impellers than for the HE-3 impellers for a given feedpipe velocity due to their principal discharge in radial direction.

\subsection{Effect of system geometry $(G / D$ and $D / T)$ on} the feedpipe backmixing

Figs. 16 and 17 present the effect of the G/D on $\mathrm{v}_{\mathrm{f}} / \mathrm{v}_{\mathrm{t}}$ for the radial feedpipe location and 6BD impellers. Overall $\mathrm{v}_{\mathrm{f}} / \mathrm{v}_{\mathrm{t}}$ was slightly decreased as $\mathrm{G} / \mathrm{D}$ was increased. The results indicated that higher impeller rotational speeds were needed for a given feedpipe velocity as the feedpipe was positioned farther away from the impeller blade tip. This result was consistent with the findings of other investigators (Bhattacharya and Kresta, 2006; Kresta and Wood, 1991) on the basis that both the radial velocity and turbulent intensity decrease with increase of the radial distance from the bladed disk turbine impeller.
However, overall $\mathrm{v}_{\mathrm{f}} / \mathrm{v}_{\mathrm{t}}$ for the HE-3 impellers stayed almost constant as G/D was increased as shown in the Figs. 18 and 19. As discussed above, HE-3 impeller is an axial flow impeller and thus, effect of G/D on $\mathrm{V}_{\mathrm{f}} / \mathrm{V}_{\mathrm{t}}$ in radial direction was relatively small compared to the 6BD impellers.

At $\mathrm{G} / \mathrm{D}=0.4$, the values of $\mathrm{v}_{\mathrm{f}} / \mathrm{v}_{\mathrm{t}}$ for $\mathrm{D} / \mathrm{T}=0.53$ were slightly higher than those for $\mathrm{D} / \mathrm{T}=0.37$. This result indicated that higher impeller tip speeds, $v_{t}$ were needed with smaller diameter impeller for a given feedpipe velocity.

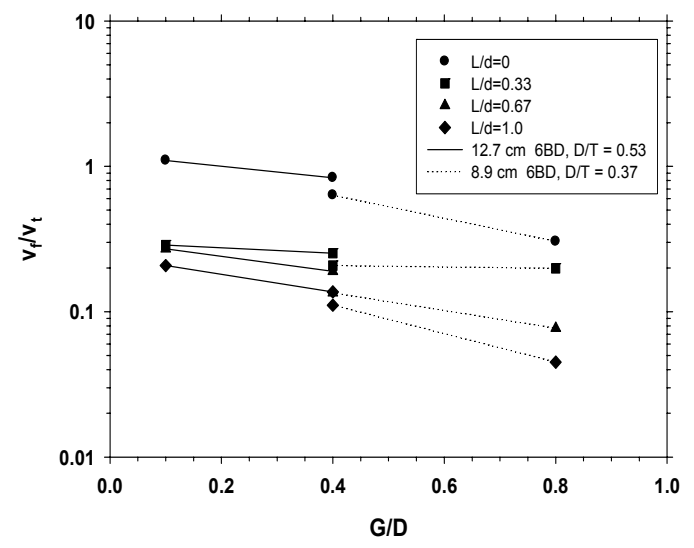

Fig. 16. Plot of $v_{f} / v_{t}$ vs $G / D$ for $6 B D$ impeller, for radial feed and for laminar flow: $\mathrm{N}_{\mathrm{Ret}}<800$.

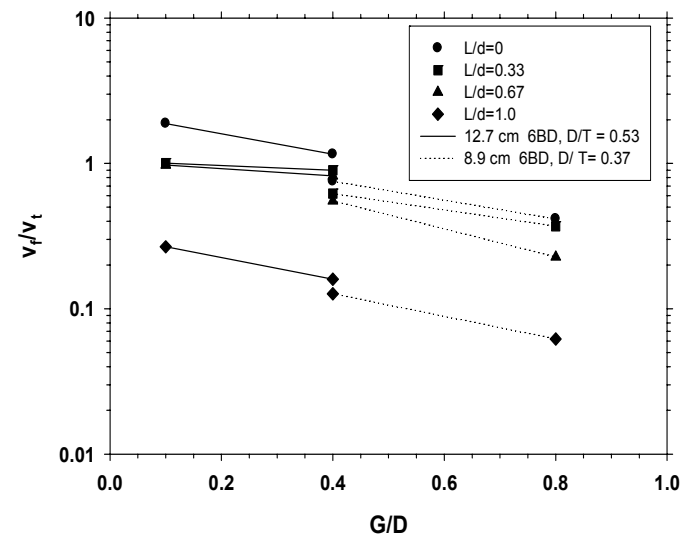

Fig. 17. Plot of $v_{f} / v_{t}$ vs G/D for $6 B D$ impeller, for radial feed and for turbulent flow: $\mathrm{N}_{\text {Ret }}>3,000$. 


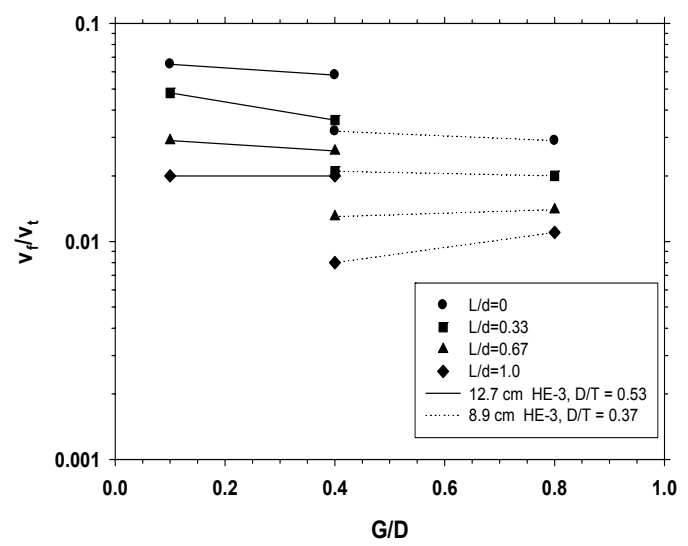

Fig. 18. Plot of $v_{f} / v_{t}$ vs G/D for HE-3 impeller, for radial feed and for laminar flow: $\mathrm{N}_{\text {Ret }}<800$.

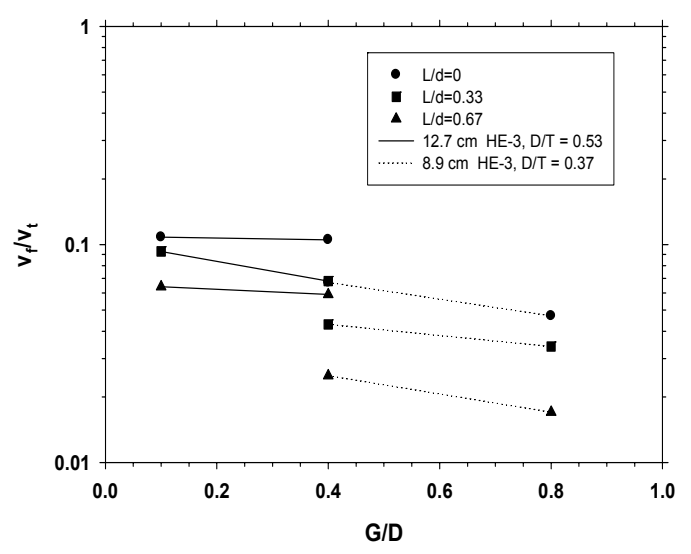

Fig. 19. Plot of $v_{f} / v_{t}$ vs G/D for HE-3 impeller, for radial feed and for turbulent flow: $\mathrm{N}_{\text {Ret }}>3,000$

3.4. Comparison of the results with those of the dye technique

Fasano et al. (1992) conducted experiments using a dye technique at low feedpipe velocity conditions which gave laminar or mildly transition flow in the feedpipe. The values of $\mathrm{v}_{\mathrm{f}} / \mathrm{v}_{\mathrm{t}}$ at feedpipe backmixing conditions were determined by observing the migration of dye back along the feedpipe counter to the feedpipe flow. However, at high feedpipe flow conditions, it was almost impossible for the naked eye to detect the fast dispersing dye. Therefore, their experiments were limited to laminar or mildly transition feedpipe flow conditions and maximum $\mathrm{N}_{\text {Ret }}$ was 1,300 .

For the $12.7 \mathrm{~cm}$ 6BD impeller the radial feedpipe location, the results could be directly compared to the results from the dye technique with the same geometrical conditions. For both $\mathrm{G} / \mathrm{D}=0.1$ and 0.4 , $\mathrm{V}_{\mathrm{f}} / \mathrm{v}_{\mathrm{t}}$ of the dye technique were much less than the values of those of the conductivity technique at $\mathrm{L} / \mathrm{d}=$ 0.67 and were slightly less than those of the conductivity technique at $\mathrm{L} / \mathrm{d}=1.0$. That is, the dye technique could not detect feedpipe backmixing until the vessel fluid penetrates one feedpipe diameter into the feedpipe.

\subsection{Comparison of the results with Bourne's reaction} data

Bourne et al. (1981b) demonstrated that feedpipe backmixing could significantly lower the yield of the primary product for the fast competitive-consecutive reaction, coupling of 1-naphthol with diazotized sulphanilic acid. With various feedpipe velocities from 0.45 to $48 \mathrm{~cm} / \mathrm{sec}$ and various feedpipe diameters from 0.1 to $0.6 \mathrm{~cm}$, the effect of feedpipe backmixing on the product distribution was investigated by varying the agitator speed under fedbatch reaction conditions. The feedpipe was positioned $1.25 \mathrm{~cm}$ below the 6BD impeller and 0.45 $\mathrm{cm}$ off the vertical centerline. Table 3 summarizes their experimental data which shows the influence of the feedpipe backmixing on the product distribution.

For a given feedpipe velocity and feedpipe diameter, $\mathrm{X}_{\mathrm{S}}$, which is the fraction of $\mathrm{B}$ used to form $\mathrm{S}$, was decreased as impeller rotational speed, $\mathrm{N}$, was initially increased. These results were expected from the fact that the intensity of mixing is increased as agitator speed is increased for a given feedpipe location. However, further increases of $\mathrm{N}$ above a certain impeller speed increased $\mathrm{X}_{\mathrm{S}}$ and thus, there existed a minimum point of $\mathrm{X}_{\mathrm{S}}$ as $\mathrm{N}$ was increased 
from low to high speed. The asterisk marked data of $\mathrm{X}_{\mathrm{S}}$ were clearly affected by feedpipe backmixing because $\mathrm{X}_{\mathrm{S}}$ increased as $\mathrm{N}$ was increased for a given feedpipe velocity. The increased level of the yield of undesirable product was due to the backmixing of reactor contents into the feedpipe where turbulent intensity is lower than in the vessel.

For each data point in Table 3, the values of $\mathrm{v}_{\mathrm{f}} / \mathrm{v}_{\mathrm{t}}$ were calculated and are given in parenthesis. They also determined feedpipe velocities and agitator speeds which produced significant feedpipe backmixing based on visual observation of the colored reaction products formed in a feedpipe (Bourne et al., 1981b). Their results for the visual experiments were as follows: $\mathrm{v}_{\mathrm{f}} / \mathrm{v}_{\mathrm{t}}=0.005$ for severe backmixing; $\mathrm{v}_{\mathrm{f}} / \mathrm{v}_{\mathrm{t}}=0.014$ for weak backmixing; $\mathrm{v}_{\mathrm{f}} / \mathrm{v}_{\mathrm{t}}$ $=0.331$ for no backmixing. When the values of $\mathrm{v}_{\mathrm{f}} / \mathrm{v}_{\mathrm{t}}$ in Table 3 were compared to theses criteria, only five conditions (bold-character numbers) showed equal or higher $\mathrm{v}_{\mathrm{f}} / \mathrm{v}_{\mathrm{t}}$ than 0.331 at or above which feedpipe backmixing was stopped according to their visual observations. Except for these data points, all the other results might have had feedpipe backmixing.

The degree of feedpipe backmixing became severe as the feedpipe velocity was decreased or the feedpipe diameter was increased for a given impeller rotational speed. The worst case occurred at the highest $\mathrm{N}=20 \mathrm{sec}^{-1}$. When the feedpipe velocity was decreased from 48 to $0.64 \mathrm{~cm} / \mathrm{sec}$, there was almost a 10 fold increase of $X_{S}$ from 0.011 to 0.10 .

The values of $\mathrm{v}_{\mathrm{f}} / \mathrm{v}_{\mathrm{t}}$ with asterisk marked data are the reduced data from the operating conditions at which $\mathrm{X}_{\mathrm{S}}$ started to increase as $\mathrm{N}$ was increased for a given feedpipe velocity and feedpipe diameter. In

Table 3. Comparison of the results of the conductivity technique with Bourne's reaction data (Bourne et al., 1981b)

\begin{tabular}{|c|c|c|c|c|c|c|c|c|c|c|c|c|c|}
\hline \multicolumn{14}{|c|}{ Bourne's reaction conditions and results } \\
\hline \multirow[t]{3}{*}{$\begin{array}{c}\mathrm{d} \\
(\mathrm{cm}) \\
\end{array}$} & $\begin{array}{c}\mathrm{V}_{\mathrm{f}} \\
(\mathrm{cm} / \mathrm{sec})\end{array}$ & $\mathrm{N}_{\text {Ret }}$ & $\begin{array}{c}\mathrm{D} \\
(\mathrm{cm})\end{array}$ & $\mathrm{G} / \mathrm{D}$ & $\mathrm{D} / \mathrm{T}$ & $\mathrm{L} / \mathrm{d}$ & \multicolumn{7}{|l|}{$\left(\mathrm{sec}^{-1}\right)$} \\
\hline & & & & & & & 0.45 & 1.22 & 3.03 & 4.97 & 7.90 & 9.95 & 20.0 \\
\hline & & & & & & & \multicolumn{7}{|l|}{$(\mathrm{vf} / \mathrm{vt})$} \\
\hline 0.6 & 0.45 & 27 & 5.08 & 0.25 & 0.37 & - & $\begin{array}{c}0.17 \\
(0.063)\end{array}$ & $\begin{array}{c}0.067 \\
(0.023)\end{array}$ & $\begin{array}{l}* 0.071 \\
(0.009)\end{array}$ & $\begin{array}{l}* 0.070 \\
(0.006)\end{array}$ & $\begin{array}{c}* 0.093 \\
(0.004)\end{array}$ & $\begin{array}{c}* 0.12 \\
(0.003)\end{array}$ & $\begin{array}{r}* 0.14 \\
(0.002)\end{array}$ \\
\hline 0.5 & 0.64 & 32 & “ & “ & “ & - & $\begin{array}{c}0.18 \\
(0.089)\end{array}$ & $\begin{array}{c}0.072 \\
(0.033)\end{array}$ & $\begin{array}{c}0.052 \\
(0.013)\end{array}$ & $\begin{array}{l}* 0.069 \\
(0.008)\end{array}$ & $\begin{array}{l}* 0.073 \\
(0.005)\end{array}$ & $\begin{array}{c}* 0.078 \\
(0.004)\end{array}$ & $\begin{array}{r}* 0.10 \\
(0.002)\end{array}$ \\
\hline 0.6 & 1.3 & 78 & “ & “ & “ & - & - & $\begin{array}{c}0.087 \\
(0.067)\end{array}$ & $\begin{array}{c}0.064 \\
(0.027)\end{array}$ & - & $\begin{array}{c}0.051 \\
(0.010)\end{array}$ & $\begin{array}{l}* 0.058 \\
(0.008)\end{array}$ & $\begin{array}{c}* 0.067 \\
(0.004)\end{array}$ \\
\hline 0.1 & 16 & 160 & “ & “ & “ & - & - & $\begin{array}{c}0.059 \\
(\mathbf{0 . 8 2 2})\end{array}$ & $\begin{array}{c}0.037 \\
(\mathbf{0 . 3 3 1})\end{array}$ & - & $\begin{array}{c}0.018 \\
(0.127)\end{array}$ & $\begin{array}{c}0.012 \\
(0.101)\end{array}$ & $\begin{array}{c}* 0.015 \\
(0.050)\end{array}$ \\
\hline 0.1 & 48 & 480 & “ & “ & “ & - & - & $\begin{array}{c}0.068 \\
\mathbf{( 2 . 4 6 7 )}\end{array}$ & $\begin{array}{c}0.029 \\
(\mathbf{0 . 9 9 3})\end{array}$ & - & $\begin{array}{c}0.018 \\
(\mathbf{0 . 3 8 1})\end{array}$ & $\begin{array}{c}0.017 \\
(0.303)\end{array}$ & $\begin{array}{r}0.011 \\
(0.151)\end{array}$ \\
\hline \multicolumn{14}{|c|}{$\begin{array}{l}\text { 6BD impeller was used. } \mathrm{V}=2.5 \text { liter; } \mathrm{G}=1.25 \mathrm{~cm} ; \mathrm{T}=15 \mathrm{~cm} \text {; numbers in parenthesis }=\text { vf/vt; *increased XS due } \\
\text { to feedpipe backmixing; bold-character numbers mean equal or higher vf/vt than } 0.331 \text { above which feedpip } \\
\text { backmixing stopped according to their visual experiment. }\end{array}$} \\
\hline \multicolumn{14}{|c|}{ Conductivity technique results } \\
\hline $\begin{array}{c}\mathrm{d} \\
(\mathrm{cm})\end{array}$ & $\begin{array}{c}\mathrm{V}_{\mathrm{f}} \\
(\mathrm{cm} / \mathrm{sec})\end{array}$ & $\mathrm{N}_{\text {Ret }}$ & $\begin{array}{c}\mathrm{D} \\
(\mathrm{cm})\end{array}$ & G/D & $\mathrm{D} / \mathrm{T}$ & $\mathrm{L} / \mathrm{d}$ & $\mathrm{vf} / \mathrm{vt}$ & & & & & & \\
\hline 0.95 & - & 400 & 8.9 & 0.25 & 0.37 & 0 & 0.133 & & & & & & \\
\hline “ & - & “ & “ & “ & “" & 0.33 & 0.055 & & & & & & \\
\hline “ & - & “ & “ & “ & “ & 067 & 0.04 & & & & & & \\
\hline “ & - & “ & “ & “ & “" & 1.0 & 0.034 & & & & & & \\
\hline
\end{tabular}

6BD impeller was used. $\mathrm{v}_{\mathrm{f}} / \mathrm{v}_{\mathrm{t}}$ were predicted for $\mathrm{G} / \mathrm{D}=0.25$ by extrapolation using the data for the above feedpipe location for $\mathrm{G} / \mathrm{D}=0.79$ based on the trend of the data for the radial feedpipe location for $\mathrm{G} / \mathrm{D}=0.36$ and 0.79 . 
other words, $\mathrm{X}_{\mathrm{S}}$ started to increase as $\mathrm{N}$ was increased above these critical operating conditions. As shown in Table 3, $\mathrm{v}_{\mathrm{f}} / \mathrm{v}_{\mathrm{t}}=0.050$ was consistent with the predicted $\mathrm{v}_{\mathrm{f}} / \mathrm{v}_{\mathrm{t}}$ for $0.33<\mathrm{L} / \mathrm{d}<0.67$ and all the other values of $\mathrm{v}_{\mathrm{f}} / \mathrm{v}_{\mathrm{t}}$ were lower than the predicted $\mathrm{v}_{\mathrm{f}} / \mathrm{v}_{\mathrm{t}}=$ 0.034 for $\mathrm{L} / \mathrm{d}=1.0$. The results of the comparison indicated that feedpipe backmixing had to penetrate at least one feedpipe diameter into the feedpipe to increase the yield of the side product. However, the yield of the side product may have not been increased, but penetration of less than one feedpipe diameter may have influenced the product distribution to a certain degree. As shown in Table $3, \mathrm{X}_{\mathrm{S}}$ for $\mathrm{v}_{\mathrm{f}}=$ $0.45,0.64$, and $1.3 \mathrm{~cm} / \mathrm{sec}$ started to deviate from those for $\mathrm{v}_{\mathrm{f}}=16$ and $48 \mathrm{~cm} / \mathrm{sec}$ at $\mathrm{N}=1.22 \mathrm{sec}^{-1} . \mathrm{v}_{\mathrm{f}} / \mathrm{v}_{\mathrm{t}}$ at the last two conditions were 0.822 and 2.467 were much higher than predicted $\mathrm{v}_{\mathrm{f}} / \mathrm{v}_{\mathrm{t}}=0.133$ for $\mathrm{L} / \mathrm{d}=0$ of the conductivity technique above which feedpipe backmixing stopped. Therefore, deviation of the yield from these two conditions implies that the yield for the other three conditions may have been influenced by feedpipe backmixing. This comparison indicates that $\mathrm{v}_{\mathrm{f}} / \mathrm{v}_{\mathrm{t}}$ higher than that for $\mathrm{L} / \mathrm{d}=0$ of the conductivity technique will certainly eliminate feedpipe backmixing in terms of conservative design criteria.

3.6. Comparison of the results with those from the fast competitive reaction of this investigation

Typical fast competitive reaction of acid-bas neutralization and alkaline hydrolysis of ethyl chloroacetate was conducted to investigate the effect of feedpipe backmixing on the product distribution. As shown in Table $4, \mathrm{X}_{\mathrm{Q}}$ for the 19.6 liter reactor initially decreased as $\mathrm{N}$ was increased. Then, $\mathrm{X}_{\mathrm{Q}}$ increased as impeller rotational speed was further increased due to feedpipe backmixing. $\mathrm{X}_{\mathrm{Q}}$ started to increase at $\mathrm{N}=300 \mathrm{rpm} . \mathrm{v}_{\mathrm{f}} / \mathrm{v}_{\mathrm{t}}$ at $\mathrm{N}=300 \mathrm{rpm}$ was 0.022 and was lower than $\mathrm{v}_{\mathrm{f}} / \mathrm{v}_{\mathrm{t}}=0.034$ for $\mathrm{L} / \mathrm{d}=1.0$ of the conductivity technique. This result was consistent with the results of Bourne's reaction experiment (Bourne et al., 1981b). That is, feedpipe backmixing must penetrate at least one feedpipe diameter into the feedpipe to increase the yield of competing reaction product, $\mathrm{X}_{\mathrm{Q}}$. The yields at $\mathrm{N}=$ 35, 100, and 200 may have been influenced by feedpipe backmixing because $\mathrm{v}_{\mathrm{f}} / \mathrm{v}_{\mathrm{t}}=0.122,0.092$,

Table 4. Operating conditions and yield of fast competitive reactions, $\mathrm{X}_{\mathrm{Q}}$, and results of the conductivity technique

\begin{tabular}{|c|c|c|c|c|c|c|c|c|c|c|}
\hline Run & $\begin{array}{c}\mathrm{d} \\
(\mathrm{cm})\end{array}$ & $\mathrm{G} / \mathrm{D}$ & $\mathrm{D} / \mathrm{T}$ & $\begin{array}{c}\mathrm{t} \\
(\mathrm{sec})\end{array}$ & $\begin{array}{c}V_{f} \\
(\mathrm{~cm} / \mathrm{sec})\end{array}$ & $\mathrm{N}_{\text {Ret }}$ & $\begin{array}{c}\mathrm{N} \\
(\mathrm{rpm})\end{array}$ & $\mathrm{V}_{\mathrm{f}} / \mathrm{v}_{\mathrm{t}}$ & $\begin{array}{c}\mathrm{C}_{\mathrm{Et}} \\
\text { (g/liter) }\end{array}$ & XQ \\
\hline \multicolumn{11}{|c|}{19.6 liter reactor; $\mathrm{a}=20, \mathrm{C}_{\mathrm{A}_{0}}=1.8$ mole/liter, $\mathrm{C}_{\mathrm{C}_{0}}=0.09$ mole/liter } \\
\hline 1 & 0.62 & 0.25 & 0.33 & 1487 & 2.18 & 97 & 35 & 0.122 & 1.277 & 0.324 \\
\hline 2 & " & “ & “" & 690 & 4.70 & 208 & 100 & 0.092 & 0.604 & 0.153 \\
\hline 3 & “" & “ & “" & 985 & 3.29 & 145 & 200 & 0.032 & 0.515 & 0.131 \\
\hline 4 & “" & “" & “" & 953 & 3.40 & 151 & 300 & 0.022 & 0.555 & 0.141 \\
\hline 5 & “" & “" & “" & 976 & 3.32 & 147 & 400 & 0.016 & 0.578 & 0.147 \\
\hline 6 & " & “" & “" & 992 & 3.27 & 145 & 500 & 0.013 & 0.527 & 0.137 \\
\hline \multicolumn{11}{|c|}{177.9 liter reactor; $\mathrm{a}=80, \mathrm{C}_{\mathrm{A}_{0}}=9.6$ mole/liter, $\mathrm{C}_{\mathrm{C}_{0}}=0.12 \mathrm{~mole} / \mathrm{liter}$} \\
\hline 1 & 0.175 & 0.25 & 0.33 & 900 & 102.74 & 1285 & 300 & 0.322 & 1.795 & 0.329 \\
\hline 2 & 0.617 & “" & “" & “" & 8.265 & 364 & 300 & 0.026 & 1.454 & 0.267 \\
\hline 3 & 1.257 & “" & “" & “" & 1.991 & 179 & 300 & 0.006 & 1.332 & 0.244 \\
\hline $\mathrm{L} / \mathrm{d}$ & \multicolumn{10}{|c|}{ Results of the conductivity technique } \\
\hline 0 & 0.95 & 0.25 & 0.37 & - & - & 400 & - & 0.133 & - & - \\
\hline 0.33 & “" & “" & " & - & - & 400 & - & 0.055 & - & - \\
\hline 0.67 & “" & “" & “" & - & - & 400 & - & 0.04 & - & - \\
\hline 1.0 & “ & “ & “" & - & - & 400 & - & 0.034 & - & - \\
\hline
\end{tabular}


and 0.032 at their respective conditions were all lower than $\mathrm{V}_{\mathrm{f}} / \mathrm{v}_{\mathrm{t}}=0.133$ for $\mathrm{L} / \mathrm{d}=0$ of the conductivity technique.

There were no increases of $\mathrm{X}_{\mathrm{Q}}$ for the 177.9 liter reactor. However, the yield for the 2 nd and 3 rd run may have been influenced by feedpipe backmixing because $\mathrm{v}_{\mathrm{f}} / \mathrm{v}_{\mathrm{t}}=0.026$ and 0.006 were lower than $\mathrm{v}_{\mathrm{f}} / \mathrm{v}_{\mathrm{t}}$ $=0.034$ for $\mathrm{L} / \mathrm{d}=1.0$ of the conductivity technique. That is, backmixing must have penetrated at least one feedpipe diameter into the feedpipe and significantly affected $\mathrm{X}_{\mathrm{Q}}$ despite the continuous increase of $\mathrm{X}_{\mathrm{Q}}$ for each condition.

\section{Conclusions}

A novel conductivity technique was successfully developed to determine the penetration depth of the vessel fluid into a feedpipe. The conductivity technique was very sensitive to the change of the conductivity of the fluid near the electrode and the ratio of detectable concentration of penetrating fluid to bulk vessel fluid concentration was on the order of $10^{-3}$. Therefore, this technique has been shown to be applicable for both laminar and turbulent feedpipe flow regimes. Compared to the dye technique, this conductivity technique could detect feedpipe backmixing at much lower impeller tip speed.

The values of $\mathrm{v}_{\mathrm{f}} / \mathrm{v}_{\mathrm{t}}$ was essentially constant for either laminar $\left(\mathrm{N}_{\text {Ret }}<800\right)$ or fully turbulent flow ( $\mathrm{N}_{\text {Ret }}>3,000$ for radial feed, $\mathrm{N}_{\text {Ret }}>2,000$ for above feed) in the feedpipe. The values of $\mathrm{v}_{\mathrm{f}} / \mathrm{v}_{\mathrm{t}}$ in the laminar flow regime were always lower than those in the turbulent flow regime. Overall $\mathrm{v}_{\mathrm{f}} / \mathrm{v}_{\mathrm{t}}$ decreased as $\mathrm{G} / \mathrm{D}$ is increased and $\mathrm{D} / \mathrm{T}$ is decreased. The values of $\mathrm{V}_{\mathrm{f}} / \mathrm{v}_{\mathrm{t}}$ for the above feedpipe location were significantly lower than those for the radial feedpipe location because of radial direction of principal discharge of 6BD impeller.

From the comparisons of the results of the conductivity technique with both Bourne's reaction results and fast competitive reaction results, it was found that feedpipe backmixing had to penetrate at least one feedpipe diameter into the feedpipe to significantly influence the yield of the side product. However, $\mathrm{v}_{\mathrm{f}} / \mathrm{v}_{\mathrm{t}}$ higher than that for $\mathrm{L} / \mathrm{d}=0$ of the conductivity technique will certainly eliminate feedpipe backmixing in terms of conservative design criteria.

\section{Acknowledgement}

This study was supported by 2010 Dongseo University Research Cluster Grant.

\section{Nomenclature}

\begin{tabular}{|c|c|}
\hline A & : volume ratio of reagent solutions $=\frac{V_{0}}{V_{A 0}}$ \\
\hline $6 \mathrm{BD}$ & : Rushton 6 bladed disk turbine impeller \\
\hline $\mathrm{C}_{\mathrm{A}_{0}} \mathrm{C}_{\mathrm{B}_{0}} \mathrm{C}_{\mathrm{C}_{0}}$ & : initial concentration of $\mathrm{A}, \mathrm{B}$, and $\mathrm{C}$ \\
\hline $\mathrm{C}_{\mathrm{C}}$ & : concentration of $\mathrm{C}$ \\
\hline $\mathrm{C}_{\mathrm{Et}}$ & : concentration of ethanol \\
\hline $\mathrm{C}_{\mathrm{R},} \mathrm{C}_{\mathrm{S}_{\mathrm{f}}}$ & : initial concentration of $\mathrm{R}$ and $\mathrm{S}$ \\
\hline $\mathrm{d}$ & : feedpipe diameter \\
\hline $\mathrm{D}$ & : impeller diameter \\
\hline $\mathrm{D}_{\mathrm{d}}$ & : impeller disk diameter \\
\hline G & $\begin{array}{l}\text { spacing between feedpipe end and impeller } \\
\text { blade tip }\end{array}$ \\
\hline $\mathrm{H}$ & : batch height in stirred tank reactor \\
\hline HE-3 & $\begin{array}{l}\text { : high efficiency axial flow type } 3 \text { bladed } \\
\text { impeller }\end{array}$ \\
\hline $\mathrm{L}$ & $\begin{array}{l}\text { distance of the electrode tip from the feedpipe } \\
\text { end }\end{array}$ \\
\hline $\mathrm{N}$ & : impeller rotational speed \\
\hline $\mathrm{N}_{\mathrm{C}}$ & $\begin{array}{l}\text { : critical impeller rotational speed to cause } \\
\text { feedpipe backmixing }\end{array}$ \\
\hline $\mathrm{N}_{\text {Ret }}$ & : feedpipe Reynolds number \\
\hline $\mathrm{R}_{\mathrm{e}}$ & : resistance of external resistor \\
\hline $\mathrm{R}_{\mathrm{P}}$ & : resistance of tap water between the electrodes \\
\hline $\mathrm{t}$ & : feed time \\
\hline $\mathrm{T}$ & : diameter of stirred tank reactor \\
\hline$v_{f}$ & : feedpipe velocity \\
\hline$v_{t}$ & : impeller tip speed $=\pi \mathrm{ND}$ \\
\hline $\mathrm{V}_{\mathrm{A}_{0}}$ & : volume of solution A added to reactor \\
\hline $\mathrm{V}_{0}$ & : initial volume of $\mathrm{B}$ and $\mathrm{C}$ \\
\hline W & : impeller blade width \\
\hline $\mathrm{W}_{\mathrm{h}}$ & : impeller blade height \\
\hline
\end{tabular}




\section{References}

Belevi, H., Bourne, J. R., Rys, P., 1981, Mixing and fast chemical reaction-II, Chem. Eng. Sci., 36, 1649-1654.

Bhattacharya, S., Kresta, S. M., 2006, Reactor performance with high velocity surface feed, Chem. Eng. Sci., 61, 3033-3043.

Bourne, J. R., Kozicki, F., Rys, P., 1981a, Mixing and fast chemical reaction-I, Chem. Eng. Sci., 36, 1643-1648.

Bourne, J. R., Kozicki, F., Moergeli, U., Rys, P., 1981b, Mixing and fast chemical reaction-III, Chem. Eng. Sci., 36, 1655-1663.

Bourne, J. R., 1982, The characterization of micromixing using fast multiple reactions, Chem. Eng. Comm., 16, 79-90.

Bourne, J. R., Rohani, S., 1983, Micro-mixing and the selective iodination of 1-tyrosine, Chem. Eng. Res. Des., 61, 297-302.

Fasano, J. B., Penney, W. R., 1991, Cut reaction by-products by proper feed blending, Chem. Eng.
Progress., 87, 46-52.

Fasano, J. B., Penney, W. R., Xu, B. C., 1992, Feedpipe backmixing in agitated vessels, AIChE. annual meeting, $111 \mathrm{C}$.

Jo, M. C., Noh, B. I., Kim, J. H., Shin, C. H., 1997, Detection of feedpipe backmixing by conductivity technique, J. Ind. Eng. Chem., 3, 318-325.

Kresta, S. M., Wood, P. E., 1991, Prediction of the three-dimensional turbulent flow in stirred tanks, AIChE., 37, 448-460.

Rice, R. W., Baud, R. E., 1990, The role of micromixing in the scale-up of geometrically similar batch reactors, AIChE., 36, 293-298.

Taylor, R. A., Penney, W. R., Vo, H. X., 2005, Scale-up methods for fast competitive chemical reactions in pipeline mixers, Ind. Eng. Chem. Res., 44, 6095-6102.

Vicum, L., Ottiger, S., Mazzotti, M., Makowski, U., Dyga, J. B., 2004, Multi-scale modeling of a reactive mixing processing in a semibatch stirred tank, Chem. Eng. Sci., 59, 1767-1781. 